\title{
Oz Never Did Give Nothing to the... Scarecrow: Neurophenomenology and Critical Pedagogy ${ }^{1}$
}

Robert Garfield McInerney, Point Park University

Email: rmcinenrey@pointpark.edu

\section{Abstract}

Using the film the Wizard of $\mathrm{Oz}$, an illustrative comparison is made between the Scarecrow's learning experiences and our own. Like we often do, the Scarecrow reduces his potential learning and thinking abilities to nothing more than the formal operations presumably at work in the brain. Ostensibly lacking this brain, the Scarecrow solves nearly all the problems encountered in the journey to Oz. A neurophenomenological description of the Scarecrow's experiences reveals his prereflective, situated learning, and embodied cognition. These ways of learning are often ignored and devalued in our educational system. Can this same method reveal our own subjugated knowledges? Herein, neurophenomenology is demonstrated as a critical pedagogy that critiques and liberates subjugated knowledge and supports a richer assessment of human learning and thinking.

\section{Introduction: The Straw Man Argument}

In this article I use the Scarecrow's adventures in the 1939 classic film The Wizard of Oz (Fleming, 1939; see also Baum, 1900) as a phenomenological anecdote (van Manen, 1990) to make pedagogical observations of situated learning and embodied cognition. ${ }^{2}$

The Scarecrow presents the straw man argument by propping up an extreme case easily disproved: "I haven't got a brain" he says, and yet he solves the vast majority of problems Dorothy and the others face. Dorothy rightly points out that he must have a brain; after all, how else could he talk? Because the brain is necessary but not sufficient for any sort of cognition, perhaps we should not ask whether the Scarecrow has a brain, but what sort of brain does he have? My central concern is with perspectives about the brain in relation to learning and thinking.

In comparing the Scarecrow's attitude with our own, I demonstrate that like us, the brain the Scarecrow values but lacks is one of Cartesianism and cognitivism. Also like us, 
interpretively the Scarecrow has a brain that can be understood as complex, embodied, and self-generating (Cilliers, 1998; Gallagher, 2005; Maturana \& Varela, 1987).

The brain the Scarecrow wishes for is merely an "impoverished image" of a neurophenomenally understood brain (Merleau-Ponty, 1962/1989, p. 431). Let us then consider a method that supports a holistic account of learning and critiques the "pervasiveness of technological and calculative practice" in our educational system (van Manen, 2007, p. 19).

\section{If I Only Had a Brain}

The Scarecrow sings about his anatomical lack: "If I only had a brain," he laments, pointing to his head. He makes the connection between his lack of a brain and his lack of abilities to learn and think. Note that the Scarecrow does not claim his inabilities stem from not having experience in the world. Nonetheless, until Dorothy comes along, he is stuck on a post with few others to associate with and no situations to be involved in.

Rene Descartes' (1980/1637) rationalism personified the idea of an isolated, nonemotional, self-reflective learner-thinker, or 'educable subject' (Fendler, 1998; Kincheloe, 2005). Descartes proposed the existence of an immaterial and disembodied rational mind (res cogitans). Although for Descartes the mind was immaterial, it was unquestionably linked to a rational thinking self: “... if such a power were in me then I would certainly be aware of it" (Descartes, 1980/1641, p.76; emphasis added). Cartesian representationalism assumes an interior space of thinking (i.e., Cartesian theatre) in which mental objects are viewed and selected for cogitating (Costall \& Still, 1991; Dennett, 1991). Common sense thinking (Denken), as Martin Heidegger (1954/1977) explains, has been historically conceived as the representations of objects and propositions that proceed from Descartes' cogito. Further, the last pages of Descartes' (1980/1641) Sixth Meditation are devoted to the brain. He relates that only a part of him is "a thing that thinks" and states, "...my mind is not immediately affected by all the parts of my body, but merely by the brain...namely, by that part in which the 'common sense' is said to be found" (p. 98).

Like Descartes' self-defining and internal thinking thing, the Scarecrow reports, "I would not be just a nothin', my head all full of stuffin." But to be an "I am," to exist, may not completely require an "I think" as a Cartesian cogito (Heidegger, 1927/1996; Merleau-Ponty, 1962/1989, p. 369). We may need things, others, and a world to have thoughts. It seems that the Scarecrow suffers from a 'Cartesian anxiety' (Bernstein, 1983) because he is unable to ground his knowledge in an absolute certainty within himself (in his brain), or within an indubitable correspondence between his brain and the world. The Scarecrow cannot see himself as a Cartesian rational perceiver, learner, and thinker; he cannot be an "I am" and so he defines himself as nothing.

Considering the aforesaid, we recognize the present-day Cartesian conception of the brain as a computational mechanism proposed by classical cognitivism (Costall \& Still, 1991; Dreyfus, 1972/1992). According to cognitivism, thinking happens when inchoate yet pre-existing internal symbolic structures assimilate information from the surrounding world and create representations which are later processed in such a way that rational behavior occurs (Costall \& Still, 1991; Ingold, 2001). When we refer to ourselves as storing, filing, downloading, and retrieving information in our minds or brains we evoke aspects of both Cartesianism and traditional cognitivism. Cognitivism has helped 
disseminate the idea that internal (mind or brain) mechanisms follow symbolic and programmatic rules (Costall \& Still, 1991). According to Valerie Walkerdine (1997):

Modern theories of cognition have taken their central plank to be that reasoning is a centralized process, occurring on the basis of a naturalistic path of development, itself guaranteed by a structural model of thinking and of the world. This view, taking some of its impetus from Descartes and some from Kant, has become an almost commonsense wisdom (p. 57).

Learning and thinking that are enactive and embodied within situations do not fit within the Cartesian and cognitivist philosophies described above (Kincheloe, 2005). Embodied, enactive, and situated learning denotes that thinking is co-emergent with the physical body, neuro-biological changes, and the surrounding eco-social-system (Gallagher, 2005; Maturana \& Varela, 1987). To understand such complexity, we need neurophenomenology which combines data from first-person subjective phenomenal reports of cognitive experience with data from third-person objective studies using, for example, EEG, or fMRI (Gallagher \& Zahavi, 2008). Neurophenomenology may be mutually 'constrained' (Varela, 1996) and 'enlightened' (Gallagher, 1997) by phenomenology and neuroscience. Neurophenomenology seeks to better understand the brain's function in relation to the lived world (Lutz \& Thompson, 2003; Thompson, Lutz, \& Cosmelli, 2005; Varela, 1996).

In what follows, I will use a method of phenomenological reflection and description as well as neurophenomenological theories to reveal the Scarecrow's everyday learning practices. As Fred Wertz (1993) makes clear: "In phenomenological psychology, one starts with description and only resorts to construction after extensive intentional analyses have established first principles and fundaments of knowledge in the discipline" (p. 22).

Beginning with phenomenology, the first aspect of my analysis addresses what Edmund Husserl (1913/1998) called the natural attitude. The natural attitude is our presumed and habitual belief in a reality that is independent of our perceptions, apperceptions, concepts, and interpretations (Gallagher \& Zahavi, 2008; Zahavi, 2003). To limit theories about the brain by staying within the natural attitude makes the brain merely an objective thing amenable to scientific investigation. But, the brain is not fully intelligible without consideration of its interrelationship with the world (Clark, 1997; Freeman, 1999; Noë, 2009; Wilson, 2004). Further, learning cannot be understood as simply input/out, cause and effect mental processing of reality within the Cartesian objectivist tradition, otherwise: "from the Cartesian perspective the curriculum becomes merely a body of finalized knowledge to be transferred to the minds of students" (Kincheloe, 2005, p. 42).

Therefore, taken for granted assumptions found within Cartesianism and cognitivism such as stored brain representations, computationalism, perception as a linear input and output system, a componentially structured brain (Clark, 1997), a brain that has a locatable executive function as well as a disembodied and world-less brain in a vat (Varela et al., 1991) are put in abeyance, or bracketed (Husserl, 1913/1998). In order to recognize and understand the style of learning I wish to describe, one must not posit the aforesaid naturalistic theories in the first place (Gallagher \& Zahavi, 2008). Bracketing presuppositions is an ongoing process and attitude (Ashworth, 1996). 
The next aspect of phenomenological analysis is a systematic investigation of the constituting structures of consciousness (e.g., intentionality, embodiment, temporality) and the givenness of the phenomenon (i.e., without scientific augmentation or experimentation). This must include a constant attempt to assure that the descriptive accounts offered remain grounded in the experience itself, and as such not solely formulated from already existing theories (Gallagher \& Zahavi, 2008; Wertz, 1993). I will outline complex actions and moods, but they hopefully will not be seen as abstractly force-fitted to the Scarecrow or, more importantly, to our experiences of learning.

To combine the above phenomenological considerations with cognitive neuroscience, I propose that the Scarecrow, like us, has a brain that can be described as autopoietic (Maturana \& Varela, 1987). The term autopoiesis means self-creating and selfgenerating: "Living beings are characterized by their autopoietic organization" (Maturana $\&$ Varela, 1987, p. 47). Autopoiesis may be applied as a theory of brain organization and function where the brain's neural traces, connectivity, and strengths are temporally and provisionally assembled, and synchronizing (Cilliers, 1998). ${ }^{3}$ The autopoietic brain recursively interacts with the eco-social system to continually reproduce, maintain, and delineate its boundaries and organization (Maturana \& Varela, 1980, 1987). The autopoietic brain does not make and store representations of the world; it is 'self-tuning' (Globus, 1995) and coupled with the surrounding eco-social system. Consequently, the autopoietic brain is plastic, adaptive, and the state of the system at any time is a byproduct of the conditions of the particular context and history of the system.

Learning becomes emergent and situated when triggering from the surrounding ecosocial system changes the state and tentative structure of the autopoietic brain (Lemke, 1997). The brain's learning and thinking capabilities are thus understood as selfgenerating (Thompson et al, 2005; Varela, 1996). Maturana and Varela (1980) explain: "Learning is not a process of accumulation of representations of the environment; it is a continuous process of transformation of behavior through continuous change in the capacity of the nervous system to synthesize it" (p. 45). Learning and perception are cognitively entwined (Neisser, 1976), and as such perception and learning happen in action with the surrounding world (Noë, 2004). Robert Wilson (2004) recognizes that "in order to understand the central aspects of cognition we look not to what's in the brain but what the brain is in" (p. 210). Furthermore, relatively recent advances in cognitive neuroscience have persuasively argued that the body and emotions must be considered as inextricably part of the processes of cognition and brain development (Clark, 2001; Freeman, 2000; Gallagher, 2005).

What is required then are descriptions of skills, accomplishments, and involvement relative to the preservation of autopoiesis and in relation to the meaning-making activity that is the foundation to perceiving, learning, and thinking (Heidegger, 1927/1996). ${ }^{4}$ As mentioned above, these examples will act as a pedagogical 'action sensitive' assessment of learning (van Manen, 1990). As van Manen (1979) suggests: "In phenomenology...examples are the methodological language through which the deep structures of experiences are explored" (p. 9). 


\section{Some People without Brains do an Awful lot of Thinking}

The Scarecrow's adventures with Dorothy make him a "new-comer" (Lave \& Wenger, 1991, p. 122). Lave and Wenger (1991) describe the new-comer as the naive apprentice who experiences learning with peripheral involvement that increases with a "growing use value of participation" and by the desire to be a "full practitioner" (p. 122). When Dorothy meets the Scarecrow he is born into a "fresh possibility of situations" (MerleauPonty, 1962/1989, p. 407). Because the Scarecrow is a new-comer, his learning and thinking can be compared to a child's early experiences and development in school.

In the film, the Scarecrow is stuck on a post at the crossroads of the yellow brick road. He tells Dorothy it is "tedious being stuck" and Dorothy compels him: "Oh, dear! That must be terribly uncomfortable. Can't you get down?" The idea of getting down seems unthinkable to the Scarecrow: "Down?" he says, with an incredulous tone (Fleming, 1939). Mirroring the bodily situation he is in, the Scarecrow's thinking is at a crossroads. When we come to a cognitive impasse and the world calls us in multiple directions, our rational self-reflection upon the problem often fails us. So we go with our gut, or our hearts - we follow our bodies toward the world. Figurative expressions such as I long for, I ache for, I feel pulled or torn, as well as twisted logic reveal the embodied and 'operative intentionality' of our indecisions (Merleau-Ponty, 1962/1989). Like the rest of us, we may stay stuck and yearning until someone or some event comes along that perturbs us.

Perturbations, according to Maturana and Varela (1987) are all interactions and interrelationships that trigger (but do not determine) observable changes in autopoietic entities (e.g., people, brains, and ecosystems). Remember that the autopoietic brain becomes distinct from its environment through its own self-creating dynamics. But, it is also interrelated with the environment and others (consensual cognitive domains), in part, via perturbations: "the being and doing of an autopoietic unity are inseparable, and this is their specific mode of organization" (Maturana \& Varela, 1987, p. 49).

An affective perturbation is any interaction or interrelationship that is emotionally charged and changes the affective disposition one finds ones' self in (Rietveld, 2008): "All cognition, because it is embodied, is necessarily also affective" (Lemke, 1997, p. 46). Dorothy's attempt to get the Scarecrow down is an affective perturbation because it changes the encompassing mood the Scarecrow has been in. Here I distinguish affect (mood) from specific emotions: affect denotes a continuum of moods that attune us to our embedded-ness in our everyday practices. An affect has little or no object, person, or event directedness. We always find ourselves in some sort of affective disposition while in, around, and about all situations in our everyday life (Heidegger, 1927/1996). There is an affective disposition to talking with a particular friend, being stuck on post, or being in school. These affective dispositions tacitly inform us of our situations. In contrast, emotions are not dispositions precisely because they have an object that positions us in a certain attentive and intentional way (Freeman, 2000). When an experience is emotional, it is directed toward an object, event, or another person; we are angry at, and in love with, upset about, and so on. As Freeman (1999) says: "We can begin to make sense of emotions by indentifying them with the intention to act, and then to note their increasing levels of complexity" (p. 125). 
With close observation we see how the affective perturbation (Dorothy's arrival) triggers an increased recognition of the affective disposition (stuckness), which leads to an event and object-directed emotion (frustration). The emotion of frustration emerges in practice and is directed to the post or pole up his back. The perturbation intensifies as Dorothy approaches and attempts to free him. What happens when Dorothy moves closer?

In the moment of frustration, we see the Scarecrow situate himself differently by waving his arms, twisting, moving his body against the post, and turning his head towards his back. He makes postural and motor adjustments (proprioception), and I suggest he is not aware in any explicit sense of the physical calibrations necessary to get down from the post (see Gallagher, 2005). Proprioception in the conventional sense is simple awareness of physical joint juxtaposition and limb movement. Gallagher (2005) tells us: "Proprioception is a tacit, prereflective awareness that constitutes the very beginning of a primitive body image" (p. 73). He differentiates proprioception as informational and as awareness. Proprioceptive information offers us more than where our body is; it tells us what our bodies can do: as Polanyi (1966) states, "Our body is the ultimate instrument of all our external knowledge, whether intellectual or practical" ( $\mathrm{p}$. 15).

When proprioceptive information and awareness combine, they offer the potential for prereflective action and an improved sense of body schema (Gallagher, 2005). The Scarecrow's newly augmented body schema (as Dorothy approaches) shows intermodal perception. Two modes of perception- exteroceptive (external) and proprioceptive (internal)- help the Scarecrow create an embodied knowledge as he uses what he senses to inform him of his situation (Gallagher, 2005). The intermodality is immediate and dynamic, not as two predetermined modules in his brain communicating information back and forth (Karmiloff-Smith, 1992), but as an unmediated emergence of body schema (Gallagher, 2005). The Scarecrow's body stuck on the post is not experienced as a collection of coordinates within an objective space. The body is not experienced as objects to other objects, as Merleau-Ponty (1962/1989) makes clear: "A movement is learned when the body has understood it" (p. 139).

When the Scarecrow is perturbed, he knows how to get down and discovers his potential body schema in the practice of movement and the desire to move on. He offers up his knowledge modestly, "Of course, I'm not bright about things but if you just bend the nail down in the back, maybe I'll just slip off' (Fleming, 1939). As Merleau-Ponty (1962/1989) states: "My body has its world, or understands its world, without having to make use of my 'symbolic' or 'objectifying' function" (pp. 140-141).

Rather than simply stored representation in the brain, one is more or less ready for a perturbation based on previous experience, or a previous action-effect (Cox \& Smitsman, 2008; Rietveld, 2009). Personal learning development in this sense is part of a dynamic eco-social system and the plasticity of the brain (Lemke, 1997; Thelen \& Smith, 1994). Therefore, to skillfully adapt to a new situation is neurologically 'softy assembled' via a complexity of previous interactions coming to fulfillment in the moment (Cilliers, 1998; Clark, 1997; Thelen \& Smith, 1994). The internal connections of the brain may be tentatively prepared and assembled so to allow an implicit process of 're-description of representations' that become explicit in learning situations (see Karmiloff-Smith, 1992). ${ }^{5}$ Therefore, neuro-cognitive representations of the world are likely to be dynamically 
distributed within the brain and lacking in centralized control (Cilliers, 1998; Clark, 1997).

\section{I'll Show You How to get Apples}

Soon after the Scarecrow and Dorothy venture off they discover the talking trees. When the trees stop Dorothy from eating their apples, the Scarecrow immediately comes to her defense claiming they do not want any of "those" apples. The trees take umbrage and they are in effect perturbed: "Are you implying that our apples are not what they ought to be?" The Scarecrow quickly responds, "It's just that she doesn't like little green worms" (Fleming, 1939). Conceivably, the Scarecrow has tacitly learned something from his previous experience with Dorothy (Polanyi, 1966). What learning emerges within this situation?

The trees are a perturbation to the Scarecrow. They trigger frustration which, as stated above, is an object, event, or person-directed emotion. The Scarecrow's frustration is with the trees not letting Dorothy have the apples. We remember the Scarecrow was recently stuck on a post and living a life of rooted and immovable existence. Likewise, the trees are rooted in the ground and we can surmise that their affective disposition, embodied abilities, and sense of body schema are similar to the Scarecrow's previously stuck existence. Gallagher (2005) explains that understanding others is primarily an 'embodied practice' and '...in most intersubjective situations we have a direct understanding of another person's intentions because their intentions are explicitly expressed in their embodied actions, and mirrored in our own capabilities for action" (p. 224). The Scarecrow knows what it is like to be stuck and then frustrated. In the moment of an additional frustration (which is the emotional trigger), he demonstrates a skillful adaptation (how to get apples) driven by a shared intersubjective affect and practice (Neisser, 1980, 1985).

Watching closely we notice Dorothy and the Scarecrow back away from the trees as the Scarecrow waves his arms. He appears to be getting the trees' attention; a beginning perturbation triggering (but not stipulating) the trees to throw the apples. "I'll show you how to get apples," the Scarecrow tells Dorothy, and he then explicitly mocks the trees becoming aware that the trees have little choice but to throw apples at them. The Scarecrow seems to recognize (empathize) that the trees will be quick-tempered and vengeful, yet unable to express their frustration in certain ways. At this instant we observe that the apples emerge as an affordance.

Affordances, according to J. J. Gibson (1979), are anything in the environment that appear and facilitate a potential for action. An affordance offers a how to for the perceiver of heretofore unrecognized actions in the environment (Rietveld, 2009; Gibbs \& Van Orden, 2003). The perceiver becomes the action, coping, and problem-solving agent she or he was not before (Costall, 1995; Good, 2007).

Heidegger's (1927/1996) explication of handiness helps us to better understand the emergence of an affordance in a situation. Readiness-to-hand is how we regularly and prereflectively understand things because it denotes how things around and about us exist in the implicit background of our engaged activity (Heidegger, 1927/1996, p. 67). Things are, in effect, ready for us and become what they are (objects) when we intend toward and interact with them. If I take a sip of tea as I type, my teacup is not experienced as an 
objectively present thing (e.g., mass, weight, density, size, shape) but as an implicit part of the situation of writing, thoughts, desire, and thirst. It lies in the background of my engaged activity. If my teacup springs a leak (i.e., breaks down), it becomes present to me as an object. In a similar transformation, if I need to hold some book pages down as I type, the teacup as ready-to-hand emerges as present-to-hand or otherwise put, as an affordance.

As we have witnessed, each affordance appears as part of a learning accomplishment and can be understood as first operating within a prereflective grasp. The affordance is not experienced as an objectively present thing and is not merely part of a logical sequencing of actions (Rietveld, 2008). The apples on the trees are enlivened by the changing situation at hand and afford an opportunity for retaliation. Apples become a weapon and expression of frustration within the eco-social-system.

It is only when the Scarecrow reflects on his achievement of getting apples to eat, that he offers an ad hoc appraisal: "Hurray!" The Scarecrow tells Dorothy, "Help yourself" (Fleming, 1939).

\section{This is a Spell This Is}

In our next example from the film, Dorothy and her friends run across a field of poppies to get to the Land of Oz. Dorothy and the Lion seem to slow down and the Scarecrow urges them to hurry on. But Dorothy becomes lethargic. We soon notice Toto is already fast asleep. Dorothy lies down beside her dog and the Cowardly Lion begins to give in to the sleepy feeling as well. What does the Scarecrow discover?

One of the key issues for the Scarecrow's problem-solving in this scene is the duration and emotional intensity of the obstruction of their goal to get to Oz. Lewis and Todd (2005) argue "that attention is focused on the obstructions to our intended actions at first, and only later, when the obstructions persist, does focal attention come to include emotional feelings themselves" (p. 214; emphasis added). The affective perturbations (Toto, Dorothy, and the Lion suddenly falling asleep) elicit specific event-directed emotions of confusion and panic which hone the Scarecrow's focus on the situation.

We observe the Scarecrow trying to help Dorothy continue on. When this fails, he tries to hold up the Lion, but again to no avail. Notice that as each of his friends gives in to the poppies, the Scarecrow's sense of the obstruction and the intensity of the affective perturbation is amplified (Lewis \& Todd, 2005). The Scarecrow's negative appraisal of the perturbation (i.e., valence) leads to an unmediated intention to act which shifts perceptive focal capabilities towards emotionally charged ways of coping (Freeman, 2000). Lewis and Todd (2005) suggest that emerging intentions, emotions, and focal shifts involve "synchronization of neural structures as a rapid self-organizing process" (p. 214; see also Freeman, 2000).

Interestingly, the drug takes effect in the following order: the smallest creature, Toto, then the mid-sized Dorothy, and finally the large Lion. Smallness and slight build signify vulnerability and one by one the smallest to largest of them succumbs to the poppies. But the Tin Man and Scarecrow remain unaffected. The reality of our susceptibilities, as well as what our bodies are made of and capable of, emerge more acutely when we are in situations that elicit them. I interpret that the Scarecrow uses his own lived sense of 
vulnerability to fathom the situation he is in. Remember, the Scarecrow lives his body as lifeless stuffing; if it catches fire, he is doomed. The Tin Man is nothing but a magically animated substance. The Scarecrow and the Tin Man are made of inert matter that cannot be affected by the drug (i.e., they are not biological). We witness how the Scarecrow projects this lived sense of his and the Tin Man's embodiment on to the situation in one fell swoop: why would his friends, mid-stride, fall asleep in a field of poppies in such an order and why are only he and the Tin Man unaffected?

Although these characters are imaginary, I urge my readers not to take the above interpretation as simply fanciful. ${ }^{6}$ Their experiences reflect ours. ${ }^{7}$ For example, as I look upon a flight of stairs it is prereflectively experienced in a different way as I age, gain weight, or if I have injured my leg. Noticing just a subtle change in posture and coloration of the skin, we may ask a friend, "Are you feeling okay?" According to Merleau-Ponty (1962/1989), "The world around us must be, not a system of objects with which we synthesize, but a totality of things, open to us, towards which we project ourselves" (p. 387). Like the Scarecrow, we know our bodies relationally to others, and to the capacities and incapacities that the world provides.

What (who) in the Scarecrow's experience could cause such a sudden (supernatural) change? Completing the perceptual cycle (Neisser, 1976), we observe the emotional appraisal of the situation. Figuring the Witch must be after them, and with no affordance emerging, the Scarecrow exclaims: "this is a spell, this is," and he calls for help (Fleming, 1939). Help arrives as magical snow on a warm and sunny day.

\section{And Toto Too?}

In the film, Toto escapes the Witch's castle, leaves Dorothy behind, and returns to the forest where they were captured. In the forest, the Tin Man and the Cowardly Lion are busy putting the Scarecrow's body back together again because he was torn apart by the flying monkeys. When Toto returns, he barks and the Tin Man and the Cowardly Lion are perplexed. What does the Scarecrow know of the totality of this situation?

First, we should understand some background experiences that the Scarecrow has had with Dorothy and Toto. The Scarecrow has witnessed Dorothy's inseparability and connection with Toto in their journey together. Toto is introduced by Dorothy as if another person. Dorothy defends Toto against the Wicked Witch, the Cowardly Lion, and the Wizard. Dorothy speaks to Toto, for Toto, and even questions him for advice. Toto follows every move Dorothy makes. Figuratively speaking, Dorothy is an extension of Toto's lived body. Dorothy and Toto are a totality (in-toto!). The aforesaid particulars are knowledges that remain in a tacit dimension of knowing (Polanyi, 1966).

The Scarecrow's body is strewn across the forest - the Tin Man quips, "That's you all over the place": from this, we realize the disembodied nature the Scarecrow is in and his emotional desire to be whole again (Fleming, 1939). At the moment of Toto's arrival, the Scarecrow lacks the lived totality he once had. Similarly, Toto lacks his totality in being without Dorothy. The Scarecrow's attention to Toto is prepared by the previous tacit knowledge and the present situation of being discombobulated. The Scarecrow's attention shows a perceptual anticipation of Toto's desire to be whole again (Neisser, 1976). Varela et al., (1991) state: "the neuronal network does not function as a one-way street from 
perception to action" (p. 163). Perception and action are interrelated in their emergence and selection. Neural interpretation proposes that sub-cortical areas of the brain are prepared for attention and action. Pre-frontal cortical areas respond via phase synchronization with sub-cortical areas that have already reacted to the emotional states given in the moment. ${ }^{8}$ Once triggered, the pre-frontal cortical areas (or neural assemblies) self-create and organize (Lewis and Todd, 2005; Gibbs \& van Orden, 2003; Thompson et al., 2005; Varela, 1995). The Scarecrow's perception is instantaneously guided as apperception.

The aforesaid is not a denial of simple reasoning, which would suggest that if Dorothy and Toto were taken away, Toto could lead them back to Dorothy. I offer an enhancement to this reasoning process. Putting these above ideas together, we recognize that Toto's arrival and barking is an affective perturbation that triggers a partiallyprepared, embodied empathy in the Scarecrow, which leads to a circularity and recursive understanding of shared desires. ${ }^{9}$ The Scarecrow's thinking is enactive in the situation as he remembers the totality of Dorothy and Toto: "Why don't you see, he's coming to take us to Dorothy!" (Fleming, 1939).

\section{Let Them Think about It}

Towards the end of the film, the Witch has the Scarecrow and the others trapped in the castle. The Scarecrow looks up at the chandelier and follows the rope down to where it is secured.

Close observation reveals the how to sequence of the Scarecrow's learning accomplish and skillful coping. The Witch and her guards provide escalating affective perturbations, such as being caught by the guards and being made to suffer ("let them think about it") before their demise (Fleming, 1939). Similar to the scene with the poppies, we recognize this as a highly-charged, emotionally-driven appraisal of an obstruction of desire and goal. Lewis and Todd (2005) tell us that “....appraisal, emotion, and intention arise together" (p. 215).

Also, I interpret that as the Scarecrow was once rooted like the trees, he was once hung up like the chandelier. He experiences an embodied recall born of the situation at hand. To see the rope's connection to the chandelier can be thought of as an instant anticipation of a pragmatic connection rather than a reflection upon a learned logical connection. The physical interconnectedness of the rope, chandelier, axe, and Tin Man are flowing and immediate: "Your body is already 'acting before you know it," as Gallagher says (2005, p. 237). The Scarecrow and the Tin Man seem to be bodily-as-one: the Scarecrow uses the Tin Man's arms as if they were his own and we witness 'absorbed skillful activity' (Dreyfus, 2002). This is, following Gallagher (2005), a 'communicative gesture' because "The performative awareness of [the body] is tied to...embodied capabilities for movement and action" (Gallagher, 2005, p. 74).

Remembering Heideggerian (1927/1996) readiness-to-hand as discussed above, we recall that "What is at hand is not thereby observed and stared at simply as something objectively present" (p. 69). Like the apples the Scarecrow used in the previous scene, the axe directly emerges as an affordance in a referential totality such that its many modes of 
use become available to the Scarecrow. Like us, the Scarecrow does not store in his brain the numerous uses of a thing in every situation. Again from Gallagher (2005):

Phenomenology tells us that our primary and usual way of being in the world is pragmatic interaction (characterized by action, involvement, and interaction based on environmental and contextual factors), rather than mentalistic or conceptual contemplation (characterized as explanation or prediction based on mental contents). (p. 212)

Additionally, we have an excellent example of what Maturana and Varela (1987) call structural coupling: non-programmatic and interconnected behaviors and actions that can be observed between operationally closed autopoietic systems (people) and their environment (see pp. 75-86). The interacting perturbations coincide with the structural coupling and congruence; they do not predetermine them. To some degree, the Scarecrow and the Tin Man have shared in the same trials and tribulations. As Christina Toren (2001) puts it, "human sociality is the bedrock condition of human autopoiesis" (p. 157). This consistency of recurrent perturbations and triggering leads to common interrelations between autopoietic agents (Thelen \& Smith, 1994). Using the axe together happens within a 'consensual domain' that is created in the dynamic interrelationship of structural coupling between autopoietic entities (Maturana \& Varela, 1987).

Consequently, a 'social phenomenon' in the form of co-ontogenies and as "coordinated behaviors mutually triggered" emerges (Maturana \& Varela, 1987, p. 193). As Maturana and Varela (1987) explain: "It is our history of recurrent interactions that makes possible our ontogenic structural drift in a structural coupling that affords interpersonal coordination of actions" (pp. 232-233). ${ }^{10}$ The structural coupling facilitates an emergence of affordances (axe and Tin Man) for skillful coping (Rietveld, 2008).

The Tin Man does not prevent the Scarecrow from using his axe and arm because there is an implicit acknowledgment within their lived experiences. If the Tin Man had reflected upon the Scarecrow's action, the Witch surely would have destroyed them. The Scarecrow and the Tin Man cut the rope and the chandelier falls on the Witch's henchman. Learning then is distributed between participants and the situation; "learning is a situated activity" (Lave \& Wenger, 1991, p. 29).

\section{By Virtue of the Authority Vested in Me}

In the original book version called The Wonderful Wizard of Oz (1900/2000) by Frank L. Baum, the Scarecrow says to the wizard, "I have come for my brains...you are quite welcome to take my head off as long as it will be a better one when you put it on again" (p. 196). Oddly, at the end of the film version, the Scarecrow is not given a new head or brain; he is awarded a diploma. The diploma is the final measure of our school instruction, and it assumedly shows we can learn and have learned. We discover what mattered was not a brain after all. The wizard is quite clear on this as he states, "anybody can have a brain" and those who go to universities "...think deep thoughts and with no more brains than you have. But they have one thing you haven't got: a diploma" (Fleming, 1939). 
Who is the Wizard to hold sway over the perceiving, learning, and thinking abilities of the Scarecrow? The Wizard says, "by virtue of the authority vested in me": the Wizard is an authority and his authority is both sovereign (centralized and forceful) and disciplinary, as Michel Foucault (1975/1995) describes. First, we recognize sovereign authority because the Wizard is the centralized "great and powerful" in $\mathrm{Oz}$ and obviously wields some coercive force (hence the elaborate fire, smoke, and light show). However, the sovereign authority is uncovered by the curtain literally being pulled away and the Wizard exposed as merely a man. No longer able to discipline through force, the Wizard enters into the domain of Foucauldian disciplinary power. The aforesaid tells us that his authority is by virtue of the inseparability of power and knowledge (Foucault, 1980). The Wizard's power is now interrelated with his knowledge of others (i.e., of their differences). He is the ruler in the sense of the one who takes the measure, legitimizes, and classifies the otherness (alterity) of others (see Ryan, 1991; Gore, 1998).

The Wizard disciplines the Scarecrow by bringing him into the discipline of proper learning and education (awarding the diploma). The Scarecrow's previous skillful coping and learning accomplishments were illegitimate or subjugated. Foucault (1980) tells us of two distinct features of subjugated knowledges: first, they are "historical contents that have been buried and disguised in a functionalist coherence or formal systemisation" ( $p$. 81). Second, subjugated knowledges are "a whole set of knowledges that have been disqualified as inadequate to their task or insufficiently elaborated; [they are] Foucault goes on "naïve knowledges, located low down on the hierarchy, beneath the required level of cognition or scientificity" (p. 82). Subjugated knowledges are always there within any system and need critical theory (genealogy) in order to be uncovered.

Descartes' rationalism as well as cognitivism helped create standardized and legitimate knowledges within school institutions (Kincheloe, 2005). Certain knowledges are made illegitimate by virtue of positivism and standardization in Western curriculum (Giroux, 1981; Kincheloe, 1991, 2005). Lave and Wenger (1991) relate that "conventional explanations view learning as a process by which a learner internalizes knowledge" and explain that "[it] establishes a sharp dichotomy between inside and outside, [and] suggests that knowledge is largely cerebral and takes the individual as the nonproblematic unit of analysis" (p. 47).

Today, educators learn that the curriculum is a precise structure (a lesson plan) for instructing (Kincheloe, 1999). Teachers must follow the accountability guidelines related to the curriculum. This means students must follow the structure, plan, and the standardizations. Students that can not think within these parameters become, according to Walkerdine (1997), "pathologized calculators" (p. 69). As Eva Simms (1999) says, the child then becomes "measured against western adult achievements in scientific thinking" (p. 310). Like the Scarecrow, students are in danger of defining themselves as "I'll be just a nothing" when Cartesianism and cognitivism completely delimit learning and thinking (see Reay \& Wiliam, 1999).

Education theorist and curriculum specialist Joe Kincheloe $(1999,2004)$ explains that critical pedagogy is concerned with genealogy and subjugated forms of knowledge. Kincheloe's (2004) critical pedagogy opposes the Cartesian modernist cognitive model I have described above. Kincheloe's (2005) critical constructivism recognizes the need to access and assess learning as a complex and dynamic phenomenon. Critical pedagogy then is an attempt to liberate knowledge from subjugation and to allow these knowledges 
to be "capable of opposition and of struggle against coercion of a theoretical, unitary, formal and scientific discourse" (Foucault, 1980, p. 85).

Curriculum specialist William Pinar (2004) proposes that curriculum be a union of our biographic past with the complexity of our biographic present thus informing a teaching style and plan. With this in mind, Pinar suggests we follow the student in an undetermined process of openness. As Kincheloe (2005) relates, "Critical constructivists always keep these autopoietic notions in mind. As they build a curriculum, they are acutely aware that knowledge emerges...from an interactive relationship between the knower (subject) and the known (object)" (p. 109).

Pinar asks us to consider learning as a process that has little or no predetermined trajectories. One way of achieving Pinar's curriculum is to use portfolio assessments. A portfolio assessment is a collection of a student's work over a protracted period of time whereby the student and the teacher decide what is representative of the student's ongoing learning process. An ontogenic-biographic portfolio (a range and selection) would track the learner's unique trajectories within eco-social-systems (Lemke, 1997). In a sense, this is what I have done herein by following the Scarecrow's learning accomplishments.

I have shown that descriptive neurophenomenological reflection reveals aspects of learning to be non-Cartesian, pre-cognitive, prereflective, bodily, and affectively moderated. Such an assessment might include first-person reports of student experience, and pedagogic phenomenological observation (van Manen, 1979; 1990). Later, research programs can combine this data with third-person imaging technologies and the like, to get a fuller sense of how we learn (i.e., the practical-practice of learning) in diverse situations.

\section{A Doctorate in Thinkology (Epilogue)}

The Scarecrow does not become marginalized or pathologized; instead, he earns a doctorate in thinkology. Thus, the Scarecrow's adventures have been a story of the "taming of wild thinking" and the construction of an educable subject (Fendler, 1998; Simms, 1999, p. 308).

With a Th.D. in hand, the Scarecrow puts his finger to his head and recites the Pythagorean Theorem. He is thrilled with his accomplishment: "Oh joy, rapture, I've got a brain. How can I ever thank you enough" (Fleming, 1939)? But when the time comes to figure out how to get Dorothy back home to Kansas, the Scarecrow, left only with his 'calculative thinking' is now at a loss (Heidegger, 1966). ${ }^{11}$ 


\section{Endnotes}

${ }^{1}$ Title adapted from the song Tin Man (1974) by the band America: "But Oz never did give nothing to the Tin Man, that he didn't, didn't already have."

${ }^{2}$ Max van Manen (1990) explains that anecdotes "form a concrete counterweight to abstract theoretical thought," "possess a certain pragmatic thrust,"[and] "offer a certain truth that is otherwise difficult to put into clear language" (pp. 199-120).

${ }^{3}$ Trace, in cognitive neuroscience, denotes a material and locatable place in the brain (Cilliers, 1998; Wilson, 1998). However, a Derridean-influenced idea of trace materializes as 'deferral and difference;' that is, trace is always under 'erasure' (see Derrida, 1973, pp. 154-158). Wilson (1998) states: "The neuropsychical trace escapes the containment of measurement and visibility pursued in contemporary neurocognitive technologies and methodologies" (p. 168).

${ }^{4}$ I have used the Scarecrow as a terra incognita (lacking subjectivity) to have the space to explore embodied and situated cognition. However, human beings' cognitive activities are permeated by meaning-making, or the disclosure of meaning in relation to all worldly situations (Heidegger, 1927/1996). Thus, I have offered no understanding of the value and significance of the Scarecrow's learning experiences which are the ground upon which all else rests (see Neisser, 1999).

${ }^{5}$ Certainly the brain re-presents the world. As Andy Clark (1997) believes, "partial reconceptions" (p. 169) regarding representational accounts of the brain can offer better "representational stories" (p. 170). However, he goes on that we must reject "those classical connotations that invite us to think of relatively simple, spatially and/or temporally-localized structures as the typical vehicles of representations" (p. 174).

${ }^{6}$ Phenomenology "appeals to our immediate common experience in order to conduct a structural analysis" and a goal of phenomenology is to "construct an animating, evocative description" (van Manen, 1990, p. 19). Every observation I offer is an interpretation. Hermeneutics, linked with phenomenology, is an interpretive praxis that necessarily includes an ongoing understanding of the interpreter as well as who and what is being interpreted (Gadamer, 1976). As Heidegger (1977) says, "How in general we pursue things (methodos), decides in advance what truth we shall seek out in things" (p. 300).

${ }^{7}$ In Linda Finlay's (2010) excellent survey and explication on phenomenological research perspectives, she warns of "ironically playful, creative presentations" losing the "experiencing subject" (p. 17). My hope is I have partially brought to life the learner as an experiencing agent within situations. Learners have 'societal-psychological agency' (Martin \& Sugarman, 1997). Agency denotes our reflective uniqueness in choosing and transcending when using the social-eco-system as a medium (see also Walkerdine, 1997).

${ }^{8}$ A neural network operates as a system of weights (relative strength of a connection) thus no neuron, unit, or node has any complete meaning. Meaning emerges within the connections as they are interrelated and activated (Cilliers, 1998). 
${ }^{9}$ See Juarrero (1999) on dynamic and self-organizing systems in relation to hermeneutics.

${ }^{10}$ Person, brain, and world are distinct because: "structural coupling between an organism and environment takes place between operationally independent systems" (Maturana \& Varela, 1987, p. 102).

${ }^{11}$ I find it fascinating that the Scarecrow's recitation of the Pythagorean Theorem is incorrect. Of course, there are lots of theories about this on the Internet.

\section{References}

Ashworth, P.D. (1996). Presuppose nothing! The suspension of assumptions in Phenomenological psychological methodology. Journal of Phenomenological Psychology, 27(1), 1-25.

Baum, L.F. (1900). The wonderful wizard of oz. Chicago: G.M. Hill Co.

Bernstein, R.J. (1983). Beyond objectivism and relativism: Science, hermeneutics, and praxis. Philadelphia: University of Pennsylvania Press.

Bunnell, D. (1974). Tin Man. (Recorded by America, produced by George Martin), on Holiday [album, track 2], London, England: AIR Studios, Warner Bros. Records.

Cilliers, P. (1998). Complexity and postmodernism: Understanding complex systems. London/New York: Routledge.

Clark, A. (2001). Mindware: An introduction to the philosophy of cognitive science. New York/Oxford: Oxford University Press.

Clark, A. (1997). Being there: Putting brain, body, and the world together again Cambridge, MA: MIT Press.

Costall, A., \& Still, A.W. (1991). Introduction: Cognitivism as an approach to cognition. In A. Still, \& A. Costall (Eds.), Against cognitivism: Alternative foundations for cognitive psychology (pp. 1-6). Hemel Hempstead: Harvester Wheatsheaf.

Costall, A. (1995). Socializing affordances. Theory \& Psychology, 5, 467-481.

Cox, Ralf, F.A. \& Smitsman, Ad W. (2008). Towards an embodiment of goals. Theory \& Psychology, 18 (3), 317-340.

Dennett, D. (1991). Consciousness explained. Boston: Little, Brown and Co. 
Derrida, J. (1973). Differance. In Speech and phenomena and other essays on Husserl's theory of signs. (D.B. Allison \& N. Garver, Trans.) Evanston: Northwestern University Press.

Descartes, R. (1980). Discourse on method and Meditations on first philosophy. Indianapolis: Hackett Publishing Co. (Original work published 1637/1641).

Dreyfus, H. (1992). What computers still can't do: A critique of artificial reason. Cambridge, MA: MIT Press. (Original work published 1972)

Dreyfus, H. (2002). Intelligence Without Representation - Merleau-Ponty's critique of mental representation the relevance of phenomenology to scientific explanation. Phenomenology and the Cognitive Sciences, 1 (4), 367-383.

Foucault, M. (1980). Two lectures in power and knowledge. In Gordon, C., (Ed.), Power/knowledge: Selected interviews and other writings (pp. 78-108). New York: Harvester Press.

Foucault, M. (1995). Discipline and punishment: The birth of the prison (A.M. Sheridan, Trans). New York: Random House. (Original translation publication 1975).

Fendler, L. (1998). What is impossible to think? A genealogy of the educated subject. In T.S. Popkewitz, \& M. Brennan (Eds.), Foucault's challenge: Discourse, knowledge, and power in education (pp. 39-62). New York: Teachers College Press.

Finlay, L. (2010). Debating phenomenological research methods. Phenomenology \& Practice, (3), (No.1), 6-25.

Fleming, V. (Director) \& L. Frank Baum (writing credits). (1939). The wizard of oz [Motion Picture]. United States: Warner Brothers.

Freeman, W.J. (1999). How brains make up their minds. London: Weidenfeld \& Nocolson.

Freeman, W.J. (2000). Emotion is essential to all intentional behaviors. In M.D. Lewis, \& I. Granic (Eds.), Emotion, development and self-organization: Dynamic systems approaches to emotional development (pp. 209-235). Cambridge, MA: Cambridge University Press.

Gadamer, H. (1976). Philosophical hermeneutics. (D. Lingus, Trans., Ed.), California: University of California Press.

Gallagher, S. (1997). Mutual enlightenment: Recent phenomenology in cognitive science. Journal of Consciousness Studies. 4 (3), 195-214. 
Gallagher, S. (2005). How the body shapes the mind. Oxford University Press.

Gallagher, S \& Zahavi, D. (2008). The phenomenological mind: An introduction to philosophy of mind and cognitive science. New York: Routledge.

Gibbs R.W., \& Van Orden, G.C. (2003). Are emotional expressions intentional? A selforganizational approach. Consciousness and Emotion, 4, 1-16.

Gibson, J.J. (1979). The ecological approach to visual perception. Boston, MA: Houghton Mifflin.

Giroux, H.A. (1981). Ideology, culture, and the process of schooling. Philadelphia: Temple University Press.

Globus, G.G. (1995). The Postmodern brain: Advances in consciousness research. John Benjamins Publishing Co.

Good, J.M.M. (2007). The affordances for social Psychology of the ecological approach to social knowing. Theory \& Psychology, 17(2), 265-295.

Gore, J. (1998). Disciplining Bodies: On the continuity of power relations in pedagogy. In T.S. Popkewitz \& M. Brennan (Eds.), Foucault's challenge: Discourse, knowledge, and power in education (pp. 231-254). New York: Teachers College Press.

Heidegger, M. (1966) Discourse on Thinking. (J.M. Anderson \& E.H. Freund, Trans.). NY: Harper and Row.(Original work published 1959).

Heidegger, M. (1977). The question concerning technology (W. Lovitt, Trans.). In D.F. Krell (Ed.), Basic writings (pp. 311-341). New York: Harper and Row. (Original work published 1954).

Heidegger, M. (1996). Being and time (J. Stambaugh, Trans.). New York: State University of New York Press. (Original work published 1927).

Husserl, E. (1998). Ideas pertaining to a pure phenomenology and to a phenomenological philosophy. (2nd book) [Rojcewicz, R., \& Schuwer, A., Trans.]. Dordrecht, The Netherlands: Kluwer Academic Publishers. (Original work published 1913).

Ingold, T. (2001). From transmission of representations to the education of attention. In $\mathrm{H}$. Whitehouse (Ed.), The debated mind: Evolutionary psychology versus ethnography. New York: Berg, Oxford International Press. 
Juarrero, A. (1999). Dynamics in action: Intentional behavior as a complex system. Cambridge: MIT Press.

Kincheloe, J.L. (1991). Teachers as researchers: Qualitative inquiry as a path to empowerment. London, New York: The Falmer Press.

Kincheloe, J.L. (1999). Rethinking intelligence: Confronting psychological assumptions about teaching and learning. London, UK: Routledge.

Kincheloe, J. L. (2004). Critical pedagogy primer. New York: P. Lang.

Kincheloe, J. L. (2005). Critical constructivism. New York: P. Lang.

Lave, J., \& Wenger, E. (1991). Situated learning: Legitimate peripheral participation. New York: Cambridge University Press.

Lemke, J.L. (1997). Cognition, context, and learning: A social semiotic perspective. In D. Kirshner, \& J. Whitson (Eds.), Situated cognition: Social, semiotic and psychological perspectives (pp. 37-57). Mahwah, NJ: Lawrence Erlbaum Associates.

Lewis, M.D., \& Todd, R.M. (2005). Getting emotional: A neural perspective on emotion, intention, and consciousness. Journal of Consciousness Studies, 12, (8-10), 21338 .

Lutz, A. \& Thompson, E. (2003). Neurophenomenology: Integrating subjective experience and brain dynamics in the neuroscience of consciousness. Journal of Consciousness Studies, 10, (9-10), 31-52.

Martin, J. and Sugarman, J. (1997). Societal-psychological constructionism: Societies, selves, traditions and fusions. Journal of Theoretical and Philosophical Psychology, 17, (2), 120-136.

Maturana, H., \& Varela, F. (1980). Autopoiesis and cognition: The realization of the living. Dordrecht: Reidel. (Original work published 1972).

Maturana, H., \& Varela, F. (1987). The tree of knowledge: The biological roots of human understanding. Boston: Shambhala Publications.

Merleau-Ponty, M. (1989). Phenomenology of perception. (C. Smith, Trans.). London: Routledge. (Original work published 1962).

Neisser, U. (1976). Cognition and reality: Principles and implications of cognitive psychology. New York: W.H. Freeman \& Co. 
Neisser, U. (1980). On 'social knowing'. Personality and Social Psychology Bulletin, 6, 601-605.

Neisser, U. (1985). Toward an ecologically oriented cognitive science. In T.M. Shlechter \& M.P. Toglia (Eds.), New directions in cognitive science (pp. 17-32). Norwood, NJ: Ablex.

Neisser, J.U. (1999). On the Use and Abuse of Dasein in Cognitive Science. The Monist, $82(2), 347-361$.

Noë A. (2009). Out of our heads: Why you are not your brain, and other lessons from the biology of consciousness. NY: Hill \& Wang.

Pinar, W.F. (2004). What is curriculum theory? Mahwah, NJ: Lawrence, Erlbaum.

Polanyi, M. (1966). The tacit dimension. NY: Doubleday.

Reay, D., \& Wiliam, D. (1999). 'I'll be a nothing': structure, agency and the construction of identity through assessment. British Educational Research Journal, 25, 3343 354.

Rietveld, E. (2008). The skillful body as concernful system of possible actions: Phenomena and neurodynamics. Theory \& Psychology, 18(3), 341-364.

Ryan, J. (1991). Observing and normalizing: Foucault, discipline, and inequality in schools. The Journal of Educational Thought, 25 (2), 106-119.

Simms, E.M. (1999). The countryside of childhood: A hermeneutic phenomenological approach to developmental psychology. The Humanistic Psychologist, 27 (3) 301328.

Thelen, E. \& Smith, L. (1994). A dynamic systems approach to the development of cognition and action. Cambridge: MIT Press.

Thompson, E., Lutz, A., \& Cosmelli, D. (2005). Neurophenomenology: An introduction for neurophilosophers. In A. Brook, \& K. Akins (Eds.), Cognition and the brain: The philosophy and neuroscience movement (pp. 40-97). New York and Cambridge: Cambridge University Press.

Toren, C. (2001). The Child in mind. In H. Whitehouse (Ed.), The debated mind: Evolutionary psychology versus ethnography (pp. 155-179). New York: Berg, Oxford International Press.

Van Manen, M. (1979). The phenomenology of pedagogic observation. Canadian Journal of Education, 4 (1), 5-16. 
Van Manen, M. (1990). Researching lived experience: Human science for an action sensitive pedagogy. NY: State University of New York Press.

Van Manen, M. (2007). Phenomenology of practice. Phenomenology and Practice, 1(1) 11-30.

Varela, F., Thompson, E. \& Rosch, E. (1991). The embodied mind. Cambridge: The MIT Press.

Varela, F. (1995). Resonant cell assemblies: A new approach to cognitive functions and neuronal synchrony. Biological Research, 28, 81-95.

Varela, F. (1996). Neurophenomenology: A methodological remedy for the hard problem. Journal of Consciousness Studies. 3: 330-350.

Varela, F. J. and Shear, J. (1999). First-person methodologies: What, why, how? Journal of Consciousness Studies, 6 (2-3), 1-14.

Walkerdine, V. (1997). Redefining the subject in situated cognition theory. In D. Kirshner, \& J. Whitson (Eds.), Situated cognition: Social, semiotic and psychological perspectives (pp. 57-70). Mahwah, NJ: Lawrence Erlbaum Associates.

Wertz, F. (1993). Cognitive psychology: A phenomenological critique. The Journal of Theoretical \& Philosophical Psychology, 13, (1), 1-24.

Wilson, E.A. (1998). Neural geographies. London: Routledge.

Wilson, R. A. (2004). Boundaries of the mind: The individual in the fragile sciences. Cambridge, U.K.: Cambridge University Press.

Zahavi, D. (2003). Husserl's phenomenology. Stanford: Stanford University Press. 